\title{
Sulfur-containing particles emitted by concealed sulfide ore deposits: an unknown source of sulfur-containing particles in the atmosphere
}

\author{
J. J. Cao ${ }^{1,2}$, Y. K. Li ${ }^{1}$, T. Jiang ${ }^{1}$, and G. Hu ${ }^{1}$ \\ ${ }^{1}$ School of Earth Science and Geological Engineering, Sun Yat-sen University, Guangzhou 510275, China \\ ${ }^{2}$ Guangdong Key Laboratory of Geological Process and Mineral Resources Exploration, Guangzhou, \\ Guangdong 510275, China
}

Correspondence to: J. J. Cao (eescjj@ mail.sysu.edu.cn)

Received: 13 August 2014 - Published in Atmos. Chem. Phys. Discuss.: 17 November 2014

Revised: 01 June 2015 - Accepted: 10 June 2015 - Published: 26 June 2015

\begin{abstract}
Sources of sulfur dioxide, sulfates, and organic sulfur compounds, such as fossil fuels, volcanic eruptions, and animal feeding operations, have attracted considerable attention. In this study, we collected particles carried by geogas flows ascending through soil, geogas flows above the soil that had passed through the soil, and geogas flows ascending through deep faults of concealed sulfide ore deposits, and analysed them using transmission electron microscopy. Numerous crystalline and amorphous sulfurcontaining particles or particle aggregations were found in the ascending geogas flows. In addition to $\mathrm{S}$, the particles contained $\mathrm{O}, \mathrm{Ca}, \mathrm{K}, \mathrm{Mg}, \mathrm{Fe}, \mathrm{Na}, \mathrm{Pb}, \mathrm{Hg}, \mathrm{Cu}, \mathrm{Zn}, \mathrm{As}, \mathrm{Ti}$, $\mathrm{Sr}, \mathrm{Ba}, \mathrm{Si}$, etc. Such particles are usually a few to several hundred nanometres in diameter with either regular or irregular morphology. The sulfur-containing particles originated from deep-seated weathering or faulting products of concealed sulfide ore deposits. The particles suspended in the ascending geogas flow migrated through faults from deepseated sources to the atmosphere. This is a previously unknown source of the atmospheric particles. This paper reports, for the first time, the emission of sulfur-containing particles into the atmosphere from concealed sulfide ore deposits. The climatic and ecological influences of these sulfurcontaining particles and particle aggregations should be assessed.
\end{abstract}

\section{Introduction}

Sources of sulfur oxides, sulfates, and organic sulfur compounds are diverse and associated with natural and anthropogenic activities. Known sources of sulfur are volatile sulfur compounds derived from animal feeding operations (Trabue et al., 2008), and aerobic decomposition of food waste (Wu et al., 2010), biogenic sulfur from rice paddies (Yang et al., 1996, 1998) and the subantarctic and Antarctic oceans (Berresheim, 1987), sulfur gas $\left(\mathrm{H}_{2} \mathrm{~S}\right.$ and $\left.\mathrm{SO}_{2}\right)$ from geothermal fields (Kristmannsdottir et al., 2000), organic sulfur compounds from sediments and immature crude oil (Sinninghe Damsté et al., 1988), sulfur oxides from the oxidation of fossil fuels (Soleimani et al., 2007), and sulfur dioxide from acid factories and volcanic eruptions (Wong, 1978; Sweeney et al., 2008). Sulfate particles are important anthropogenic aerosols influencing climate (Pósfai et al., 1997; Williams et al., 2001). Furthermore, volcanic activity is a major contributor of sulfur to the atmosphere (ZredaGostynska et al., 1993; Graf et al., 1998; Streets et al., 2000; Seino et al., 2004; Bhugwant et al., 2009; Bao et al., 2010; Gieré and Querol, 2010), particularly in countries such as Japan, Indonesia, Réunion Island, the Philippines, Iceland, Guatemala, and New Zealand (Rose et al., 1986; Andres et al., 1993; Streets et al., 2000; Seino et al., 2004; Chenet et al., 2005; Bhugwant et al., 2009).

Stratospheric sulfur adds very little to the environmental consequences of the anthropogenic sulfur that is released in the troposphere and deposits within days to weeks (Wong, 1978; Chenet et al., 2005). Existing research shows that $\mathrm{SO}_{2}$ 
is oxidized to $\mathrm{SO}_{4}^{2-}$ in both the gas and liquid phases. Moreover, sulfate aerosols can directly affect the climate (Graf et al., 1998). In our previous work, particles carried by an ascending geogas flow in the soil (Holub et al., 1999, 2001; Cao et al., 2009, 2010b, 2011; Liu et al., 2011; Wei et al., 2013; $\mathrm{Hu}$ et al., 2015) were studied and found to contain sulfur. Further research showed that sulfur-containing particles carried by ascending geogas flows can be transported through the soil layers and into the atmosphere. Sulfur-containing particles suspended in the ascending geogas flow migrate through faults from deep-seated concealed sulfide ore deposits to the Earth's surface. These particles are a previously unknown source of sulfur-containing particles in the atmosphere. This paper reports, for the first time, the emission of sulfur-containing particles into the atmosphere from concealed sulfide ore deposits. Because concealed sulfide ore deposits are widely distributed, the influence of sulfurcontaining particles derived from them is important. The climatic and ecological effects of these particles should be studied.

\section{Methods}

Particles carried by an ascending geogas flow above the soil (that had flown through the soil), in the soil, and in deepseated faults, were collected at the Dongshengmiao polymetallic sulfide deposit in the Inner Mongolia autonomous region, China. Particles carried by the ascending gas flow in the soil were also collected at other concealed ore deposits containing sulfide minerals, such as the Kafang copper deposit of the southern Yunnan province, the Yongshengde copper deposit in northeastern Yunnan, and the Qingmingshan copper-nickel sulfide deposit in Guangxi province, China.

Particles transported by the ascending geogas flow above the soil (that had flown through the soil) were sampled using stainless steel tubes and carbon-coated nickel transmission electron microscopy (TEM) grids. The length of the stainless steel tubes was $40 \mathrm{~cm}$ and their diameter was $2.8 \mathrm{~cm}$. These tubes were inserted vertically into the soil to a depth of about $30 \mathrm{~cm}$. A carbon-coated nickel TEM grid was fixed to the end of the stainless steel tubes. The ascending geogas flow in the soil moved into the stainless steel tubes and naturally passed through the $30 \mathrm{~cm}$ soil layer. Then, the gas flow passed through the $10 \mathrm{~cm}$ of the empty stainless steel tubes above the soil. Finally, the geogas flow arrived at the top of the tubes. Particles carried by the geogas flow were adsorbed onto the carbon-coated nickel TEM grid. A protective device was installed on the outside of the steel tubes to ensure that particles sampled were those carried by the ascending geogas flow. The protective device is a cylindrical polyethylene terephthalate bottle. A small hole at the side of the bottle allowed the outflow of ascending geogas flow; however, adsorption material placed in the hole did not allow the external particles to enter. Sampling devices were installed between
25 July and 23 August 2013, and the carbon-coated nickel TEM grids were retrieved on 8 September 2013. Sampling sites were distributed across a fault above the concealed sulfide ore bodies of the Dongshengmiao polymetallic sulfide deposit.

Particles transported by the ascending geogas flow in the soil were collected using ordinary plastic funnels. An inverted funnel was inserted in a hole that was $60-80 \mathrm{~cm}$ deep and backfilled with soil, and a TEM grid was fixed to the end of the funnel spout with nylon net. The setup was protected from contamination using plastic pipes and cups. The TEM grids were retrieved after 60 days.

Particles carried by ascending geogas flows in deep-seated faults were sampled using two methods. In the first method, an active sampling device with a vacuum pump, polyvinyl chloride (PVC) pipe and carbon-coated nickel TEM grid were used as the main components. One end of the PVC pipe was connected with a tubing to the pump. A drilling steel was inserted slantwise into the fault. The inserted depth was $30-50 \mathrm{~cm}$. As the drilling steel was pulled out, the PVC pipe was inserted into the hole. The PVC pipe was compacted using a fault gouge. The impurity gases in the PVC pipe were pumped out using the vacuum pump, then, the PVC pipe was quickly sealed. A day later, we connected a tube equipped with a carbon-coated nickel TEM grid to the PVC pipe. The gas was pumped using a vacuum pump and flowed through the TEM grid for 1 to $2 \mathrm{~h}$. Particles carried by the gas were collected by the TEM grid. Finally, the carbon-coated nickel TEM grid was removed and sealed in a sample cell. The second method did not use a vacuum pump. A carbon-coated nickel TEM grid was fixed to the end of the PVC pipe. The ascending geogas flow in the fault flowed into the PVC pipe and arrived at the top of the PVC pipe naturally. The particles carried by the geogas flows in the faults were adsorbed onto the carbon-coated nickel grid. The sampling devices were installed on 03-10 August 2013, and the TEM grids were retrieved on 7 September 2013.

High-resolution TEM analyses were performed using a Tecnai G2 F30 S-TWIN instrument at Yangzhou University, China, using an accelerating voltage of $300 \mathrm{kV}$. The grids were checked using TEM before sampling, to ensure they were devoid of particles.

\section{Results}

\subsection{Sulfur-containing particles carried by an ascending geogas flow above the soil (that had flown through the soil)}

According to the TEM analysis, particles containing high levels of $\mathrm{S}, \mathrm{O}, \mathrm{Pb}, \mathrm{Zn}, \mathrm{Fe}, \mathrm{Hg}$, As, etc, were found in the ascending gas flows above the soil above the Dongshengmiao polymetallic sulfide deposit. Table 1 provides the number of sulfur-containing particles or particle aggregations that were 
Table 1. Number of sulfur-containing particles or particle aggregations number from the Dongshengmiao deposit on $100 \mu \mathrm{m} \times 100 \mu \mathrm{m}$ TEM grids.

\begin{tabular}{|c|c|c|c|c|c|c|c|}
\hline \multicolumn{4}{|c|}{$\begin{array}{l}\text { Sulfur-containing particles or particle aggregations } \\
\text { carried by ascending gas flow above the soil (that } \\
\text { had flown through the soil) }\end{array}$} & \multicolumn{4}{|c|}{$\begin{array}{l}\text { Sulfur-containing particles or particle aggregations carried } \\
\text { by ascending gas flow in deep faults }\end{array}$} \\
\hline Sample & Sample box & Grid & Number & Sample & Sample box & Grid & Number \\
\hline ND13-1 & A1 & A1-1 & 3 & NDDW03 & A2 & A2-2 & 3 \\
\hline ND13-2 & A2 & A2-1 & 2 & NDDW05 & A4 & A4-1 & 1 \\
\hline \multirow[t]{2}{*}{ ND13-3 } & A3 & A3-2 & 1 & & & A4-2 & 29 \\
\hline & & A3-3 & 6 & NDDW06 & A5 & A5-2 & 1 \\
\hline \multirow[t]{2}{*}{ ND13-4 } & A4 & A4-1 & 1 & NDDW07 & B1 & B1-1 & 4 \\
\hline & & A4-2 & 2 & & & B1-2 & 1 \\
\hline \multirow[t]{3}{*}{ ND13-6 } & A5 & A5-1 & 1 & NDDW19 & D3 & D3-2 & 1 \\
\hline & & A5-2 & 3 & & & D3-3 & 2 \\
\hline & & A5-3 & 1 & NDDW26 & E4 & E4-1 & 1 \\
\hline \multirow[t]{3}{*}{ ND13-8 } & B2 & B2-1 & 1 & & & E4-3 & 1 \\
\hline & & B2-2 & 6 & NDDW27 & E5 & E5-1 & 2 \\
\hline & & B2-3 & 1 & & & E5-3 & 2 \\
\hline \multirow[t]{3}{*}{ ND13-9 } & B3 & B3-1 & 1 & & & E5-4 & 1 \\
\hline & & B3-2 & 1 & NDDW36 & G4 & G4-1 & 12 \\
\hline & & B3-3 & 1 & & & G4-3 & 10 \\
\hline \multirow[t]{2}{*}{ ND13-10 } & B4 & B4-1 & 1 & & & G4-4 & 1 \\
\hline & & B4-3 & 6 & NDDW37 & G5 & G5-1 & 1 \\
\hline ND13-11 & B5 & B5-1 & 1 & & & & \\
\hline
\end{tabular}

found on the $100 \mu \mathrm{m} \times 100 \mu \mathrm{m}$ TEM grid. In general, one aggregation included more than five particles. Figure 1 shows an elliptical particle (ID: 1) having a diameter of $500 \mathrm{~nm}$. The particle contains $78.17 \% \mathrm{~S}$ and $18.47 \% \mathrm{O}$ (Table 2). Its $\mathrm{O}$ to $\mathrm{S}$ atomic ratio is 0.47 . Figure 2 shows a particle aggregation (ID: 2) that consists of several small particles having a diameter of $3-8 \mathrm{~nm}$. It contains $31.23 \% \mathrm{~S}$ and $59.29 \% \mathrm{Hg}$. The spacing of the lattice fringes was measured to be $0.333 \mathrm{~nm}$. Figure 3 shows particle aggregations (ID: 3 ) with sizes of less than $100 \mathrm{~nm}$. Their $\mathrm{O}$ to $\mathrm{S}$ atomic ratio is 0.51 . The particle aggregations contain $14.48 \% \mathrm{~Pb}$. The particle (ID: 4) illustrated in Fig. 4 is elliptical with a diameter of $200 \mathrm{~nm}$ and contains $18.55 \% \mathrm{As}, 54.2 \% \mathrm{~Pb}$, and $8.34 \% \mathrm{Zn}$. The particle (ID: 5) shown in Fig. 5 contains $2.25 \%$ Co. It is amorphous and has an $\mathrm{O}$ to $\mathrm{S}$ atomic ratio of 2.91. The particle aggregation (ID: 6) illustrated in Fig. 6 contains $62.39 \% \mathrm{Cu}$ and consists of small particles, each having a diameter of 5-10 nm. Figure 7 presents a particle aggregation (ID: 7) that consists of many small particles with diameters of about $5 \mathrm{~nm}$, and contains $69.28 \% \mathrm{~Pb}$

\subsection{Sulfur-containing particles carried by an ascending gas flow in the soil}

Numerous sulfur-containing particles transported by an ascending gas flow were found in the soil over sulfide ore deposits. Figure 8 shows an aggregation of such particles from the Dongshengmiao polymetallic sulfide deposit. The aggregation (ID: 8) may be composed of $\mathrm{CaSO}_{4}$ with trace

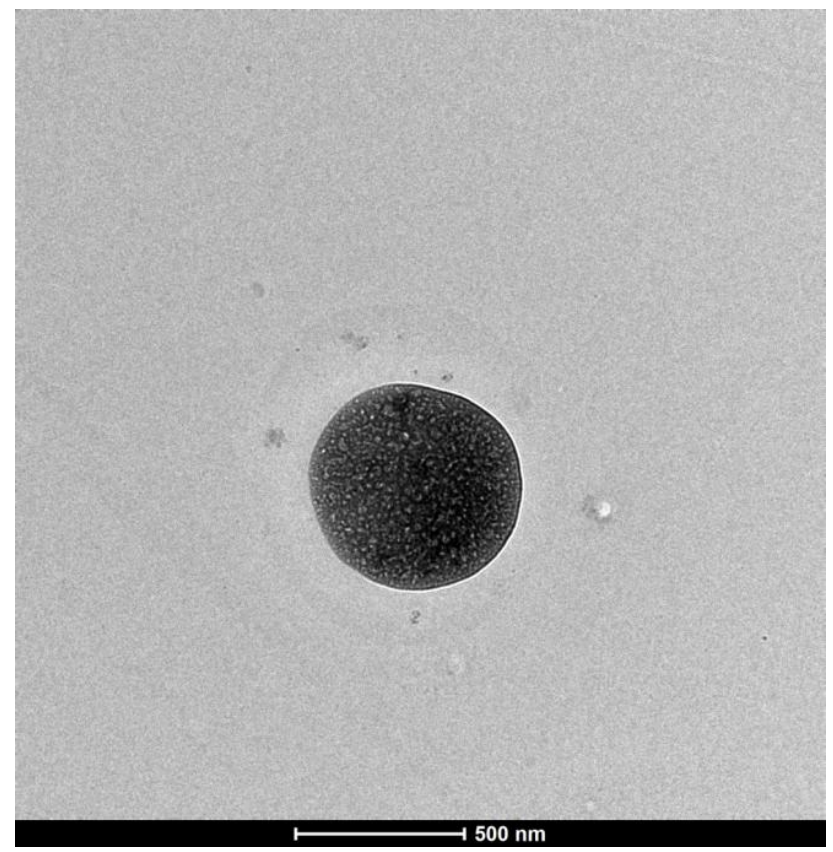

Figure 1. TEM image of an S-, O-, and Si-containing particle obtained from an ascending gas flow above the soil over the Dongshengmiao deposit.

amounts of $\mathrm{K}, \mathrm{Mg}, \mathrm{Fe}$, and $\mathrm{Si}$. It is regularly shaped and $300 \mathrm{~nm}$ in size. The selected area electron diffraction pattern 
Table 2. EDX results for particles 1-8.

\begin{tabular}{|c|c|c|c|c|c|c|c|c|}
\hline \multirow{2}{*}{ Element } & \multicolumn{8}{|c|}{ Particle number } \\
\hline & 1 & 2 & 3 & 4 & 5 & 6 & 7 & 8 \\
\hline Weight $\mathrm{O} \%$ & 18.47 & 9.46 & 16.02 & 9.73 & 15.75 & 12.9 & 5.13 & 51.88 \\
\hline Atomic $\mathrm{O} \%$ & 31.1 & 31.78 & 31.12 & 39.3 & 34.16 & 31.35 & 22.74 & 69.78 \\
\hline Weight Si\% & 3.35 & & 1.49 & 0.5 & 1.09 & 3.08 & & 2.19 \\
\hline Atomic Si\% & 3.21 & & 1.65 & 1.15 & 1.34 & 4.27 & & 1.67 \\
\hline Weight S\% & 78.17 & 31.23 & 63.1 & 3.82 & 10.83 & 21.61 & 18.25 & 19.02 \\
\hline Atomic S\% & 65.68 & 52.33 & 61.16 & 7.7 & 11.72 & 26.2 & 40.32 & 12.76 \\
\hline Weight $\mathrm{Hg} \%$ & & 59.29 & & & & & & \\
\hline Atomic $\mathrm{Hg} \%$ & & 15.87 & & & & & & \\
\hline Weight $\mathrm{K} \%$ & & & 4.88 & & 35.75 & & 7.31 & 0.99 \\
\hline Atomic K\% & & & 3.88 & & 31.73 & & 13.25 & 0.54 \\
\hline Weight $\mathrm{Pb} \%$ & & & 14.48 & 54.2 & 22.5 & & 69.28 & \\
\hline Atomic $\mathrm{Pb} \%$ & & & 2.17 & 16.9 & 3.76 & & 23.67 & \\
\hline Weight $\mathrm{Na} \%$ & & & & 3.1 & 9.66 & & & \\
\hline Atomic $\mathrm{Na} \%$ & & & & 8.73 & 14.58 & & & \\
\hline Weight $\mathrm{Fe} \%$ & & & & 0.75 & 2.14 & & & 0.21 \\
\hline Atomic $\mathrm{Fe} \%$ & & & & 0.87 & 1.33 & & & 0.08 \\
\hline Weight Co\% & & & & 0.98 & 2.25 & & & \\
\hline Atomic $\mathrm{Co} \%$ & & & & 1.08 & 1.32 & & & \\
\hline Weight Zn\% & & & & 8.34 & & & & \\
\hline Atomic $\mathrm{Zn} \%$ & & & & 8.24 & & & & \\
\hline Weight As\% & & & & 18.55 & & & & \\
\hline Atomic As\% & & & & 16 & & & & \\
\hline Weight $\mathrm{Cu} \%$ & & & & & & 62.39 & & \\
\hline Atomic $\mathrm{Cu} \%$ & & & & & & 38.16 & & \\
\hline Weight $\mathrm{Mg} \%$ & & & & & & & & 3.86 \\
\hline Atomic $\mathrm{Mg} \%$ & & & & & & & & 3.42 \\
\hline Weight $\mathrm{Ca} \%$ & & & & & & & & 21.82 \\
\hline Atomic $\mathrm{Ca} \%$ & & & & & & & & 11.71 \\
\hline
\end{tabular}

shows that the aggregation is polycrystalline, possibly gypsum. Figure 9 shows a TEM image of a sulfur-containing particle (ID: 9) from the Kafang copper deposit, South China. Sulfur accounts for $63.99 \%$ of the particle (Table 3), and its $\mathrm{O}$ to $\mathrm{S}$ atomic ratio is 0.83 . Its $\mathrm{K}$ content is $8.93 \%$, and its size is $330 \mathrm{~nm}$. Figure 10 shows a regularly polygonal particle (ID: 10) from the Yongshengde copper deposit, China. Its $\mathrm{O}$ to $\mathrm{S}$ atomic ratio is 3.60 , and its $\mathrm{Fe}$ and $\mathrm{F}$ contents are 9.94 and $1.71 \%$, respectively. Figure 11 shows a sulfur-containing particle (ID: 11) from the Qingmingshan $\mathrm{Cu}-\mathrm{Ni}$ sulfide deposit, Guangxi province, China. Its $\mathrm{O}$ to $\mathrm{S}$ atomic ratio is 2.51 . The particle contains $2.03 \% \mathrm{Co}$ and is $300 \mathrm{~nm} \times 400 \mathrm{~nm}$ in size. The selected area electron diffraction pattern shows that the particle is amorphous.

\subsection{Sulfur-containing particles carried by ascending geogas flows in deep-seated faults}

Sulfur-containing particles were found in samples obtained using two methods from the deep fault gas of the Dongshengmiao polymetallic sulfide deposit. Figure 12 shows a sulfur-containing particle aggregation (ID: 12) that was ob- tained using the vacuum pump from the deep-seated fault gas near a concealed ore body. The aggregation contains $\mathrm{O}, \mathrm{Na}$, $\mathrm{Si}, \mathrm{S}, \mathrm{K}, \mathrm{Fe}, \mathrm{Zn}$, and $\mathrm{Pb}$. The $\mathrm{S}$ content is $23.8 \%$. Figure 13 shows a particle aggregation (ID: 13) that was obtained using a PVC pipe from a fault near a concealed ore body. The ascending gas flow arrived at the top of the PVC pipe naturally, and the particles were adsorbed by a TEM nickel grid. The particle aggregation consists of many small particles that are $4-15 \mathrm{~nm}$ in diameter. The small particles are elliptical and crystalline, with $0.302 \mathrm{~nm}$ spacing of the lattice fringes, and their main components are $\mathrm{O}$ and $\mathrm{S}$. Figure 14 shows a sulfurcontaining particle (ID: 14) that was sampled using a PVC pipe in a fault above a concealed ore body. The vertical distance from the sample to the concealed ore body was $85 \mathrm{~m}$. The vertical distance from the sample to the Earth's surface was $230 \mathrm{~m}$.

\subsection{Sulfur-containing particles in deep-seated fault gouges and oxidized ores}

Sulfur-containing particles were also found in deep-seated fault gouges and oxidized zones of the Dongshengmiao 
Table 3. EDX results for particles 9-16.

\begin{tabular}{|c|c|c|c|c|c|c|c|c|}
\hline \multirow{2}{*}{ Element } & \multicolumn{8}{|c|}{ Particle number } \\
\hline & 9 & 10 & 11 & 12 & 13 & 14 & 15 & 16 \\
\hline Weight $\mathrm{O} \%$ & 26.54 & 56.25 & 53.66 & 25.39 & 67.03 & 17.21 & 29.21 & 40.8 \\
\hline Atomic $\mathrm{O} \%$ & 42.51 & 73.54 & 70.2 & 37.32 & 80.72 & 35.83 & 64.85 & 62.97 \\
\hline Weight Si\% & 0.52 & & & 0.66 & 1 & 0.7 & & 1.5 \\
\hline Atomic $\mathrm{Si} \%$ & 0.47 & & & 0.55 & 0.68 & 0.83 & & 1.32 \\
\hline Weight S\% & 63.99 & 31.3 & 42.81 & 23.8 & 28.01 & 24.59 & 10.88 & 15.03 \\
\hline Atomic S\% & 51.15 & 20.42 & 27.95 & 17.45 & 16.83 & 25.53 & 12.05 & 11.58 \\
\hline Weight $\mathrm{K} \%$ & 8.93 & 0.78 & & 2.01 & 2.59 & & & \\
\hline Atomic K\% & 5.85 & 0.42 & & 1.21 & 1.27 & & & \\
\hline Weight $\mathrm{Pb} \%$ & & & & 4.25 & & & & \\
\hline Atomic $\mathrm{Pb} \%$ & & & & 0.48 & & & & \\
\hline Weight $\mathrm{Na} \%$ & & & 1.04 & 40.92 & & 1.35 & & \\
\hline Atomic $\mathrm{Na} \%$ & & & 0.95 & 41.84 & & 1.96 & & \\
\hline Weight $\mathrm{Fe} \%$ & & 9.94 & 0.44 & 1.11 & 1.35 & 51.16 & 1.27 & 5.2 \\
\hline Atomic $\mathrm{Fe} \%$ & & 3.72 & 0.16 & 0.46 & 0.46 & 30.5 & 0.81 & 2.3 \\
\hline Weight Co\% & & & 2.03 & & & & & 6.36 \\
\hline Atomic $\mathrm{Co} \%$ & & & 0.72 & & & & & 2.66 \\
\hline Weight $\mathrm{Zn} \%$ & & & & 1.82 & & & & \\
\hline Atomic $\mathrm{Zn} \%$ & & & & 0.65 & & & & \\
\hline Weight $\mathrm{Mg} \%$ & & & & & & 2.74 & & \\
\hline Atomic $\mathrm{Mg} \%$ & & & & & & 3.75 & & \\
\hline Weight $\mathrm{Ca} \%$ & & & & & & 0.28 & 0.5 & 31.08 \\
\hline Atomic $\mathrm{Ca} \%$ & & & & & & 0.23 & 0.44 & 19.15 \\
\hline Weight F\% & & 1.71 & & & & & & \\
\hline Atomic F\% & & 1.88 & & & & & & \\
\hline Weight Al\% & & & & & & 0.25 & & \\
\hline Atomic Al\% & & & & & & 0.3 & & \\
\hline Weight Mn\% & & & & & & 1.68 & & \\
\hline Atomic $\mathrm{Mn} \%$ & & & & & & 1.02 & & \\
\hline Weight Ti\% & & & & & & & 10.94 & \\
\hline Atomic $\mathrm{Ti} \%$ & & & & & & & 8.11 & \\
\hline Weight $\mathrm{Sr} \%$ & & & & & & & 10.32 & \\
\hline Atomic $\mathrm{Sr} \%$ & & & & & & & 4.18 & \\
\hline Weight $\mathrm{Ba} \%$ & & & & & & & 36.86 & \\
\hline Atomic $\mathrm{Ba} \%$ & & & & & & & 9.53 & \\
\hline
\end{tabular}

polymetallic sulfide deposit. For example, Fig. 15 shows a sulfur-containing particle (ID: 15) from the oxidized zone. According to its atomic percentage, it contains $\mathrm{SO}_{4}^{2-}$ and may be $\mathrm{Sr}, \mathrm{Ba}$ sulfate, and $\mathrm{Ti}$ oxide. Its size is $200 \mathrm{~nm} \times 400 \mathrm{~nm}$. Figure 16 shows a rhombus-shaped particle (ID: 16) from a deep-seated fault gouge. Its main components are $\mathrm{O}, \mathrm{S}$, and $\mathrm{Ca}$, with minor amounts of $\mathrm{Fe}, \mathrm{Co}$, and Si.

Overall, the sulfur-containing particles or particle aggregations transported by ascending geogas flows can be both regular and irregular in shape and either crystalline or amorphous. The particles or particle aggregations contain $\mathrm{Ca}, \mathrm{K}$, $\mathrm{Mg}, \mathrm{Fe}, \mathrm{Na}, \mathrm{Pb}, \mathrm{Hg}, \mathrm{Cu}, \mathrm{Zn}, \mathrm{As}, \mathrm{Ti}, \mathrm{Sr}, \mathrm{Ba}$, and $\mathrm{Si}$, as well as $\mathrm{O}$ and $\mathrm{S}$.

The number of sulfur-containing particles in the ascending geogas flows in non-sulfur-rich areas is much lower than that in the sulfide ore deposits. Furthermore, the overwhelming majority of particles in non-sulfur-rich areas have a low sulphur content. These areas are different from those with the sulfide ore deposits, in which sulfur-containing particles are densely distributed and are present at high levels in the ascending geogas flows.

\section{Discussion and conclusions}

Gold particles are formed by post-mineralization fault activity, oxidation, and bacterial weathering of primary minerals (Cao et al., 2010a). Deep-seated gold particles can be transported to the surface by an ascending gas flow, as Brownian motion enables the gold particles in the ascending gas flow to overcome the effect of gravity (Cao et al., 2010a; Cao, 2011). We assume that the same mechanism applies to 


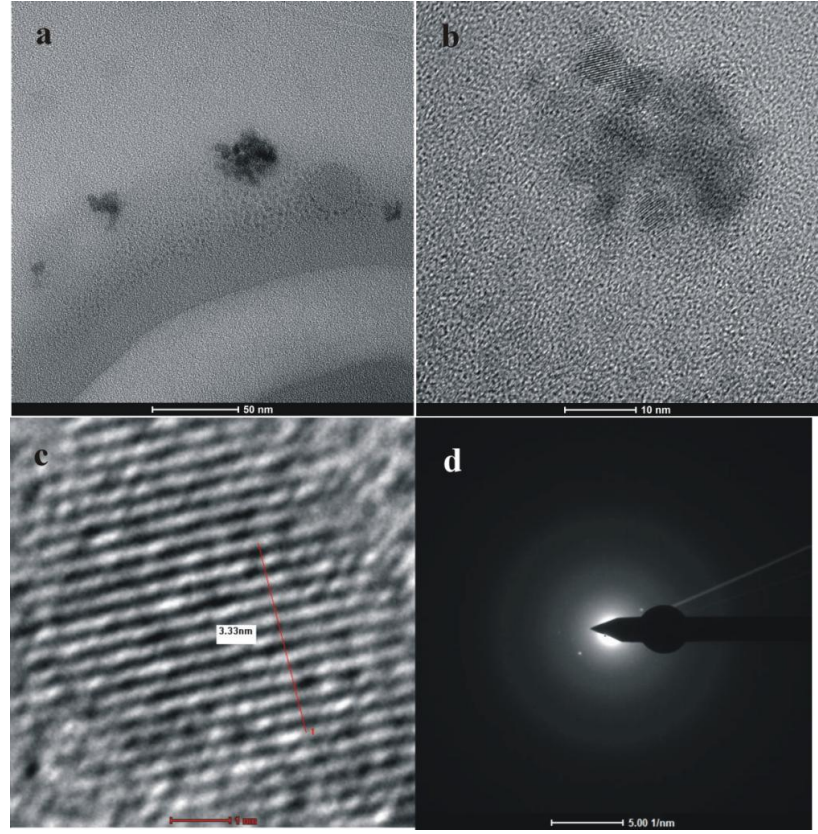

Figure 2. Panel (a) shows the TEM image, (b), (c) high-resolution (HRTEM) images, and (d) selected area electron diffraction (SAED) pattern of an S-, O-, $\mathrm{Hg}$-containing particle aggregation obtained from an ascending gas flow above the soil over the Dongshengmiao deposit.

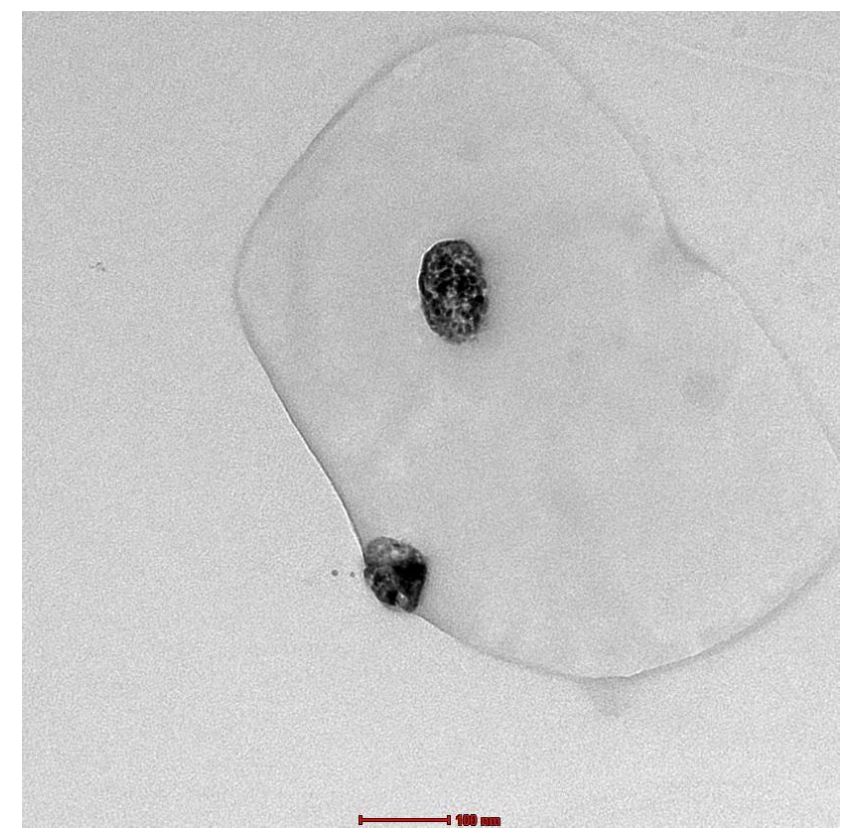

Figure 3. TEM image of S-, O-, K-, and $\mathrm{Pb}$-containing particle aggregations obtained from an ascending gas flow above the soil over the Dongshengmiao deposit.

sulfur-containing particles or particle aggregations. Primary sulfur-containing minerals are transformed into particles by

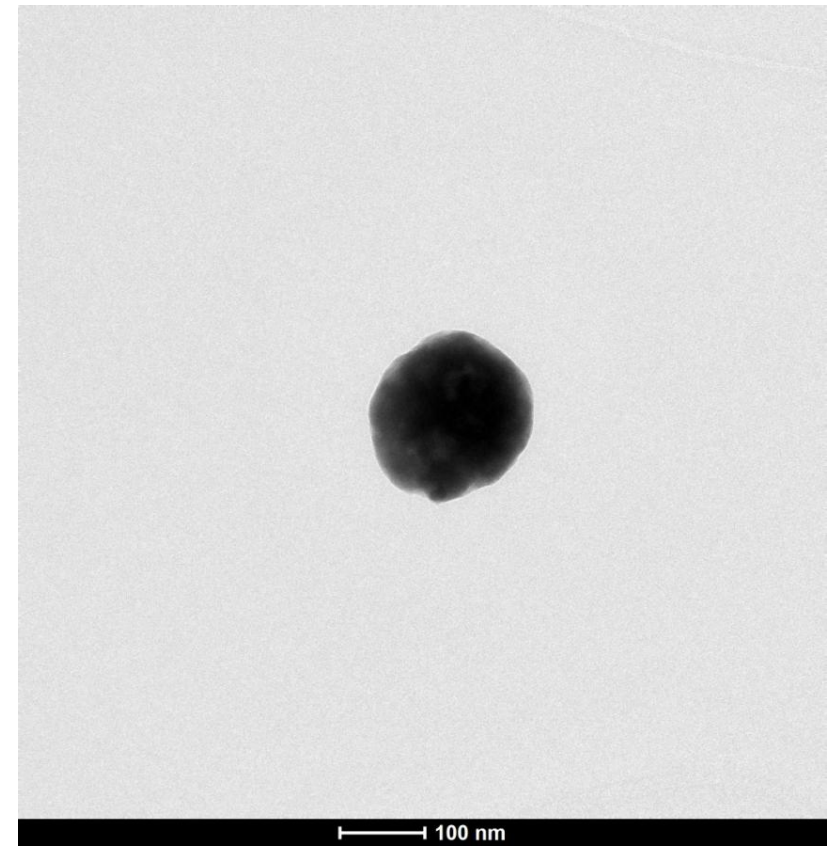

Figure 4. TEM image of an S-, O-, Na-, $\mathrm{Pb}-, \mathrm{Zn}-$, and As-containing particle obtained from an ascending gas flow above the soil over the Dongshengmiao deposit.

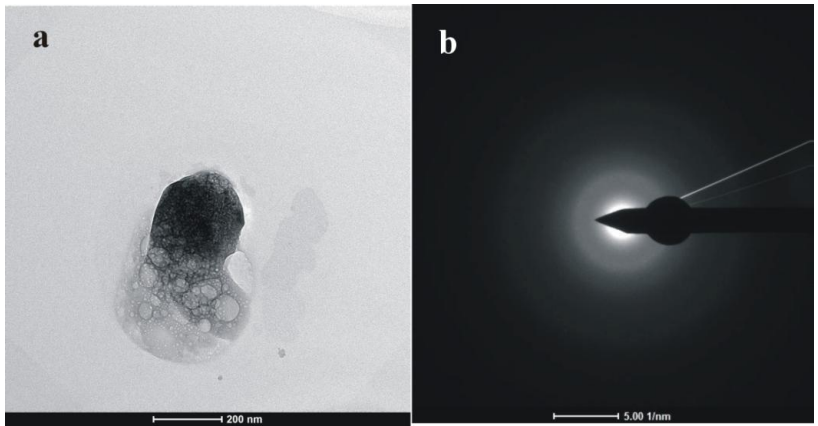

Figure 5. Panel (a) shows the TEM image and (b) SAED pattern of an S-, O-, K-, Na-, and $\mathrm{Pb}$-containing particle obtained from an ascending gas flow above the soil over the Dongshengmiao deposit.

epigenetic reworking, such as post-mineralization fault activity, in which $\mathrm{S}^{2-}$ in the sulfide minerals is oxidized to $\mathrm{S}^{6+}$. In this study, the sulfur-containing particles from fault gouges and oxidized ores were found, indicating that these particles were formed by the faulting and oxidation of ores. Faulting and oxidation are well-developed in the Dongshengmiao polymetallic sulfide deposit and other sulfide deposits. This finding indicates that faulting and oxidation play an important role in particle formation.

Sulfur-containing particles may be transported to the surface by an ascending geogas flow through faults (Etiope and Martinelli, 2002; Cao et al., 2010a). Material carried by an ascending geogas flow in the soil in the Xuanhan gas field, 


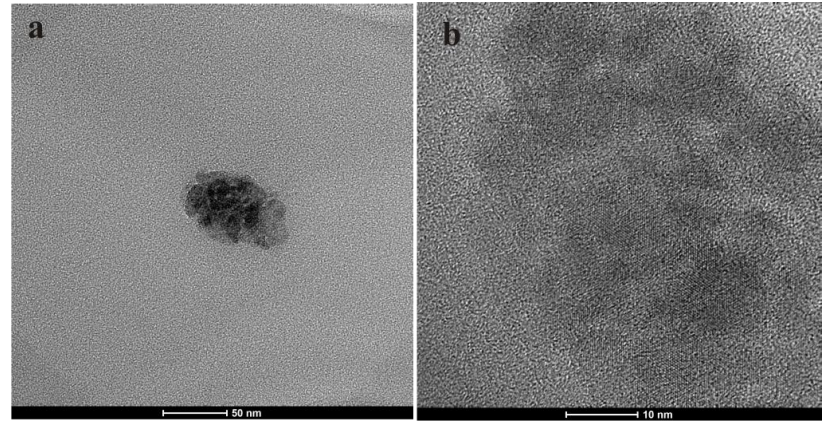

Figure 6. Panel (a) shows the TEM image and (b) HRTEM image of an $\mathrm{O}-, \mathrm{Si}_{-}, \mathrm{S}-$, and $\mathrm{Cu}$-containing particle aggregation obtained from an ascending gas flow above the soil over the Dongshengmiao deposit.

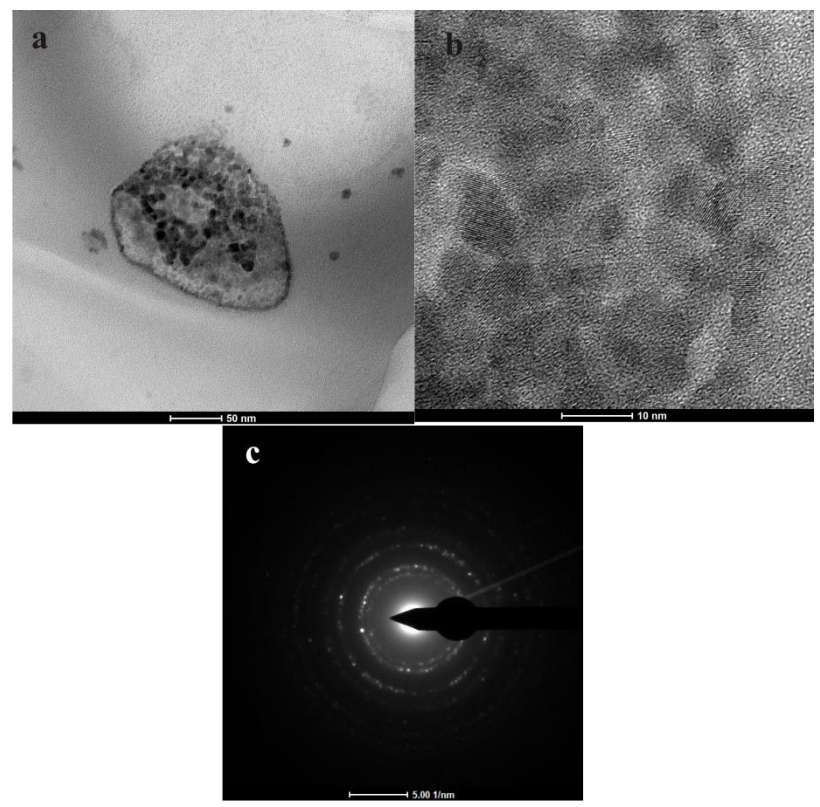

Figure 7. Panel (a) shows the TEM image, (b) HRTEM image, and (c) SAED pattern of an O-, S-, K-, and $\mathrm{Pb}$-containing particle aggregation obtained from an ascending gas flow above the soil over the Dongshengmiao deposit.

Sichuan province, China was sampled and measured using an instrumental neutron activation analysis. Analysis of trace element anomalies has shown the gas-bearing ring fracture structure to be $4000 \mathrm{~m}$ deep, suggesting that particles carried by an ascending geogas flow can be transported over long distances (Yang and Tong, 2000). The gas flow migrates upward because of the temperature difference and the pressure differences between the Earth's interior and its surface (Tong and Li, 1999; Etiope and Martinelli, 2002; Cao et al., 2010a). In this study, sulfide-containing particles suspended in gas above the soil were found, showing that these particles can move through the soil and get into the atmosphere.

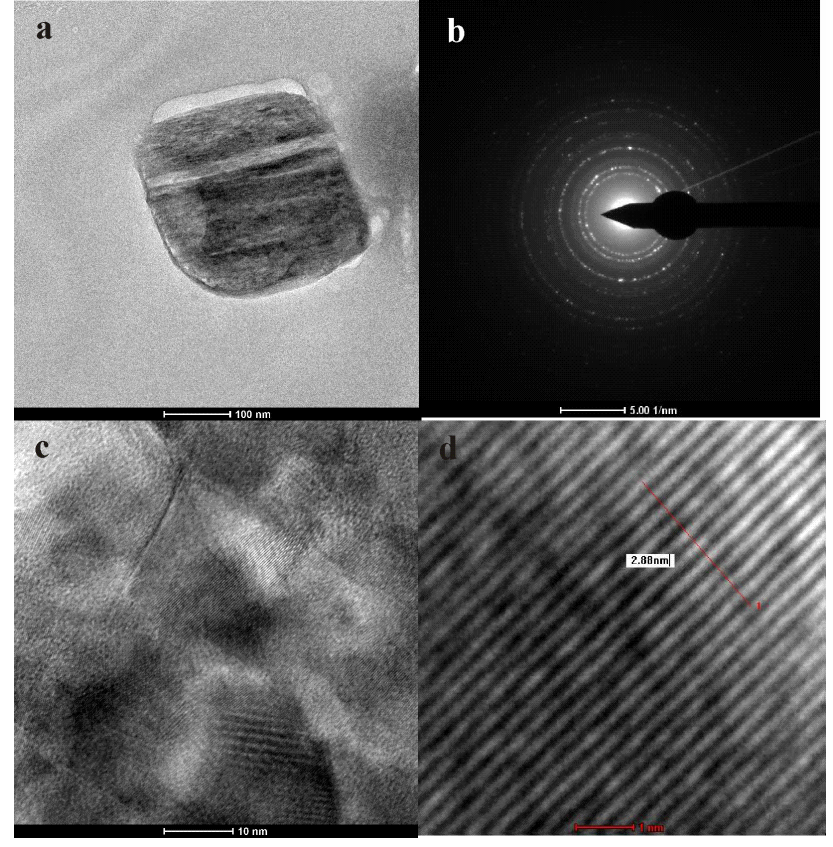

Figure 8. Panel (a) shows the TEM image, (b) SAED pattern, and (c), (d) HRTEM image of an O-, S-, Ca-, and Mg-containing particle obtained from an ascending gas flow in the soil over Dongshengmiao deposit.

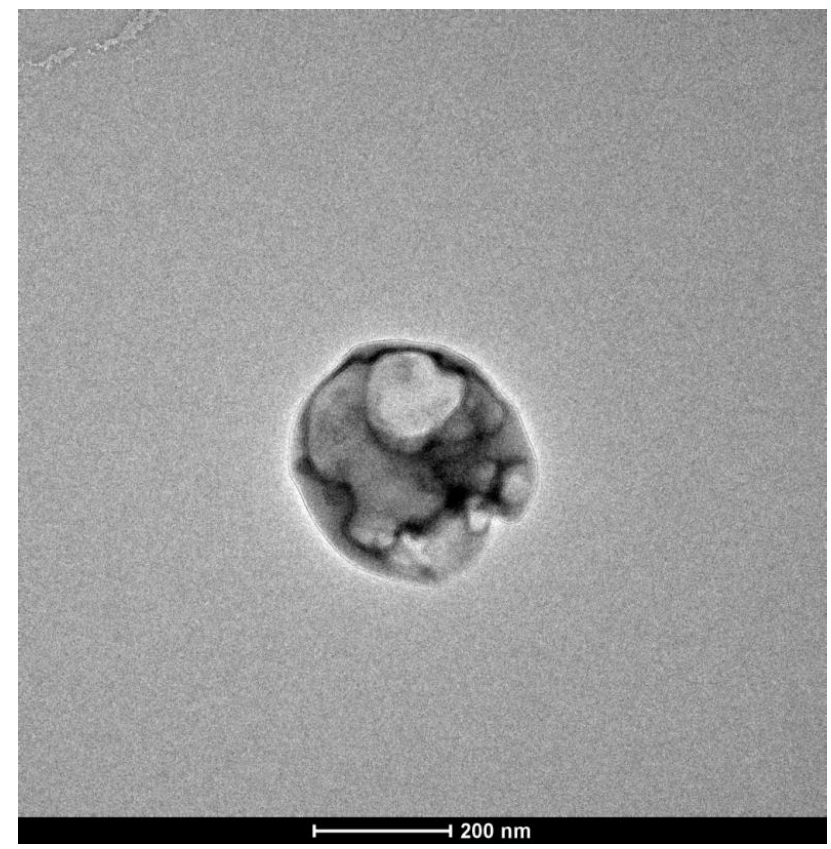

Figure 9. TEM image of an O-, S-, and K-containing particle obtained from an ascending gas flow in the soil from the Kafang copper deposit, Yunnan province.

The probability that these particles are transported by an ascending geogas flow originating in the soil is low. In the 


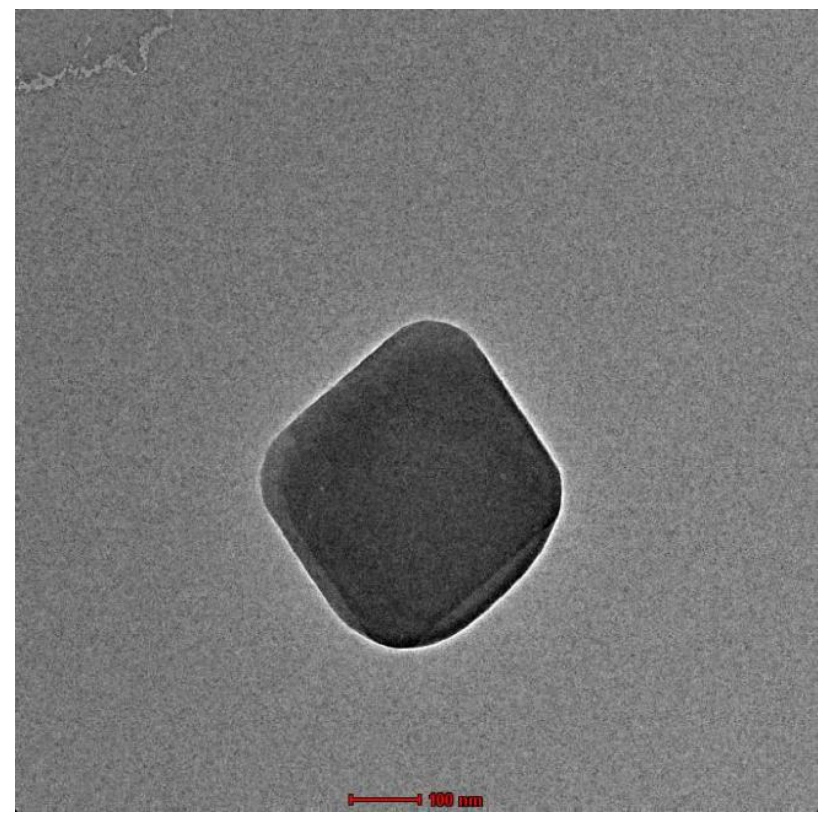

Figure 10. TEM image of an O-, S-, and Fe-containing particle obtained from an ascending gas flow in the soil from the Yongshengde copper deposit in northeastern Yunnan.

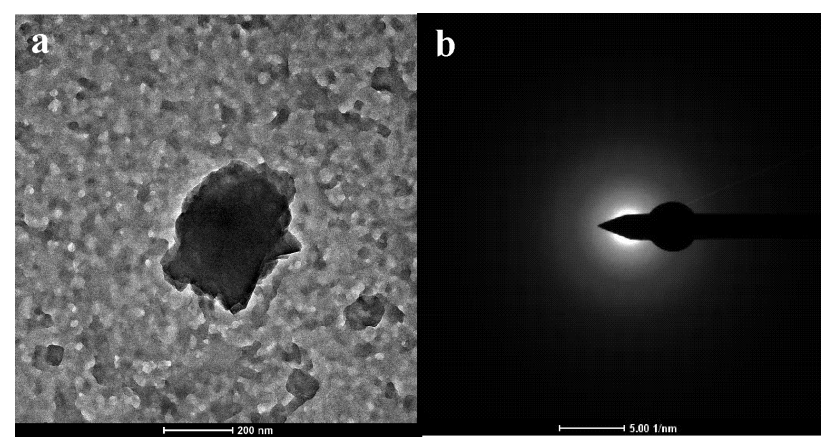

Figure 11. Panel (a) shows the TEM image and (b) SAED pattern of an O-, S-, and Co-containing particle obtained from an ascending gas flow in the soil from the Qingmingshan $\mathrm{Cu}-\mathrm{Ni}$ sulfide deposit, Guangxi province.

study area, the soil consists of kaolinite, halloysite, montmorillonite, illite, chlorite, hematite, quartz, goethite, and similar minerals. Kaolinite is the main mineral, and the sulfur content in the soil is low. Therefore, this soil is clearly not a probable source of sulfur-containing particles transported by an ascending geogas flow. Furthermore, there is no correlation between the numbers of these particles and those of sulfur-containing particles in the soil solid phase. Sulfur-containing particles are clearly enriched in soils above deep sulfur-rich sources because sulfur-containing particles transported by an ascending geogas flow were found in 16 deep sulfide ore bodies that were studied. This result indicates a close relationship between sulfur-containing particles

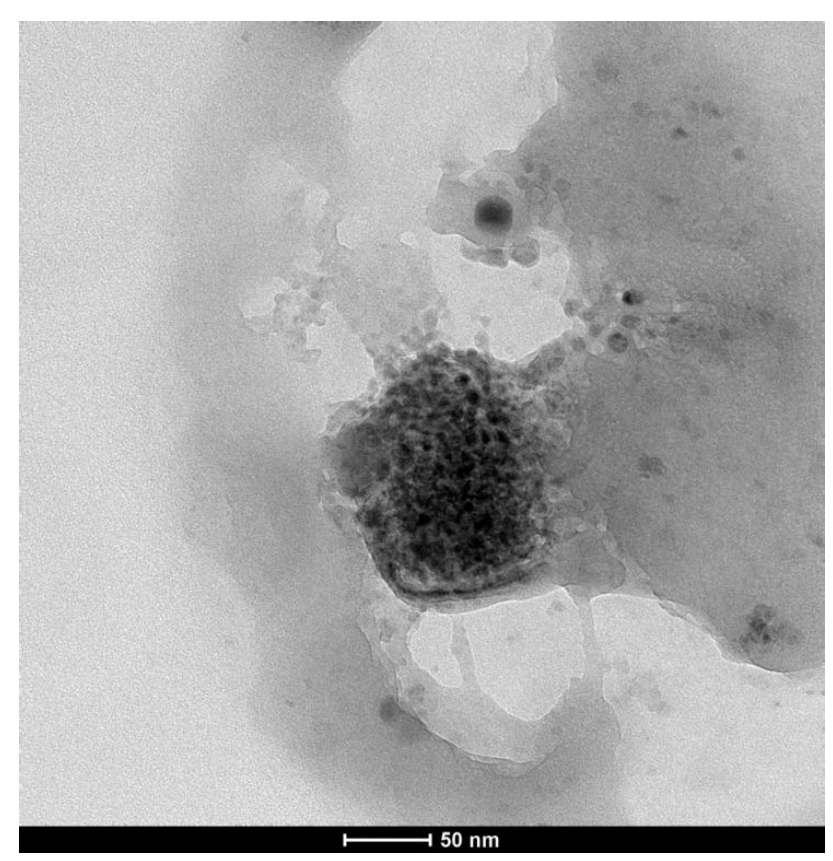

Figure 12. TEM image of an $\mathrm{O}-, \mathrm{S}-, \mathrm{K}-, \mathrm{Pb}-$, and $\mathrm{Na}$-containing particle sampled using a vacuum pump from the fault gas near a concealed ore body of the Dongshengmiao deposit.

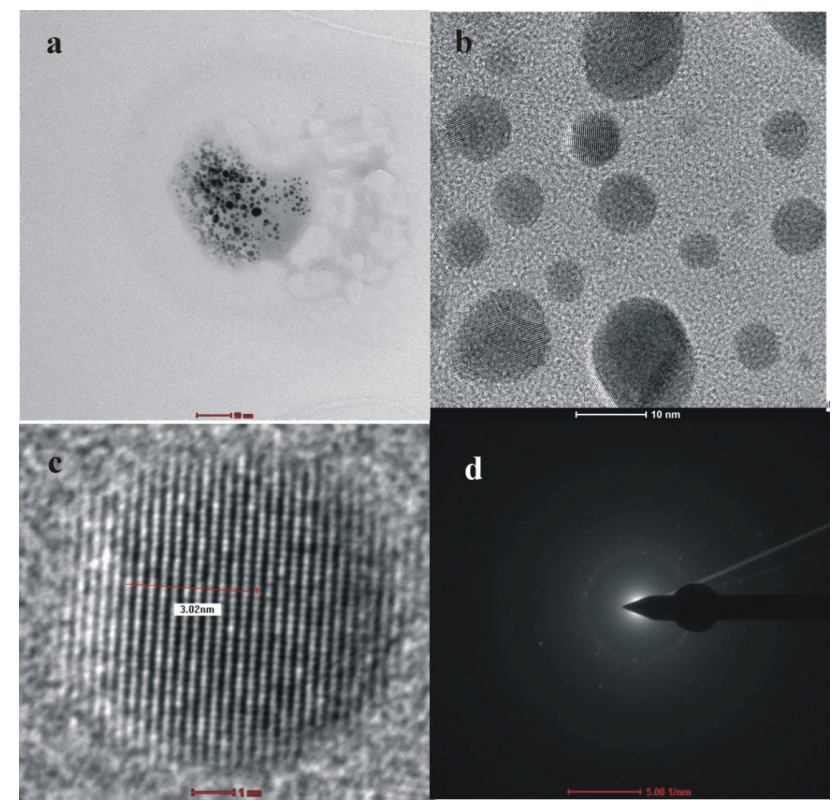

Figure 13. Panel (a) shows the TEM image, (b), (c) HRTEM images, and (d) SAED pattern of an O-, S-, and K-containing particle aggregation sampled using a PVC pipe in a fault near a concealed ore body of the Dongshengmiao deposit.

in the gas flow and deep-seated sulfide ore bodies. Other rock types, such as limestone, siltstone, sandstone, and mudstone do not contain sufficient sulfur to become sources of 


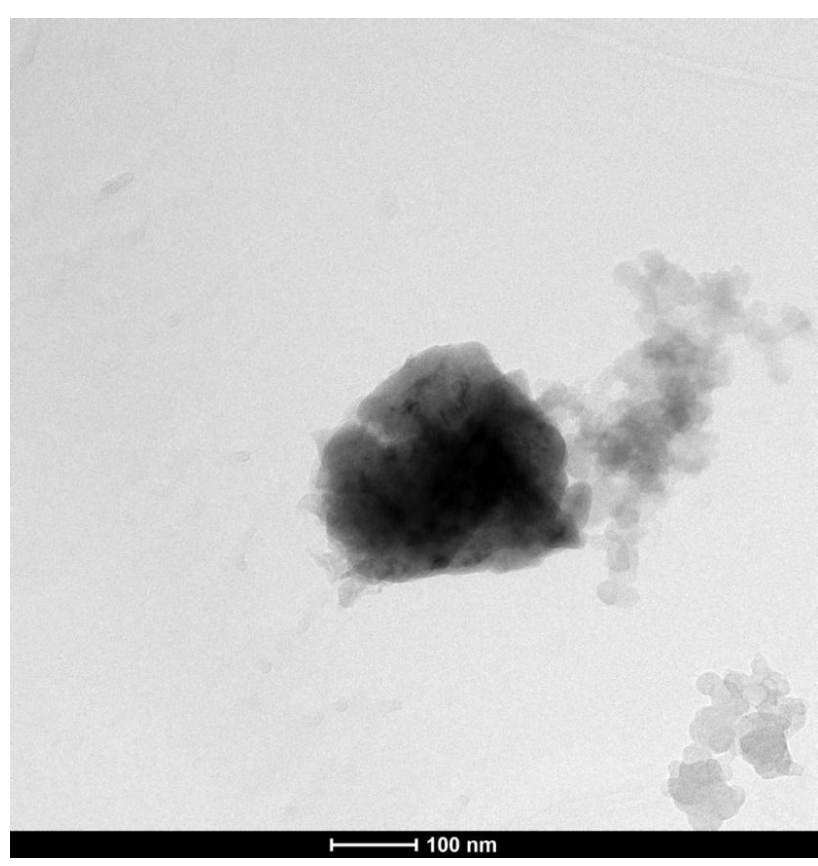

Figure 14. TEM image of an $\mathrm{O}-, \mathrm{S}-, \mathrm{Fe}-$, and $\mathrm{Mg}$-containing particle aggregation sampled using a PVC pipe in a fault above a concealed ore body of the Dongshengmiao deposit.

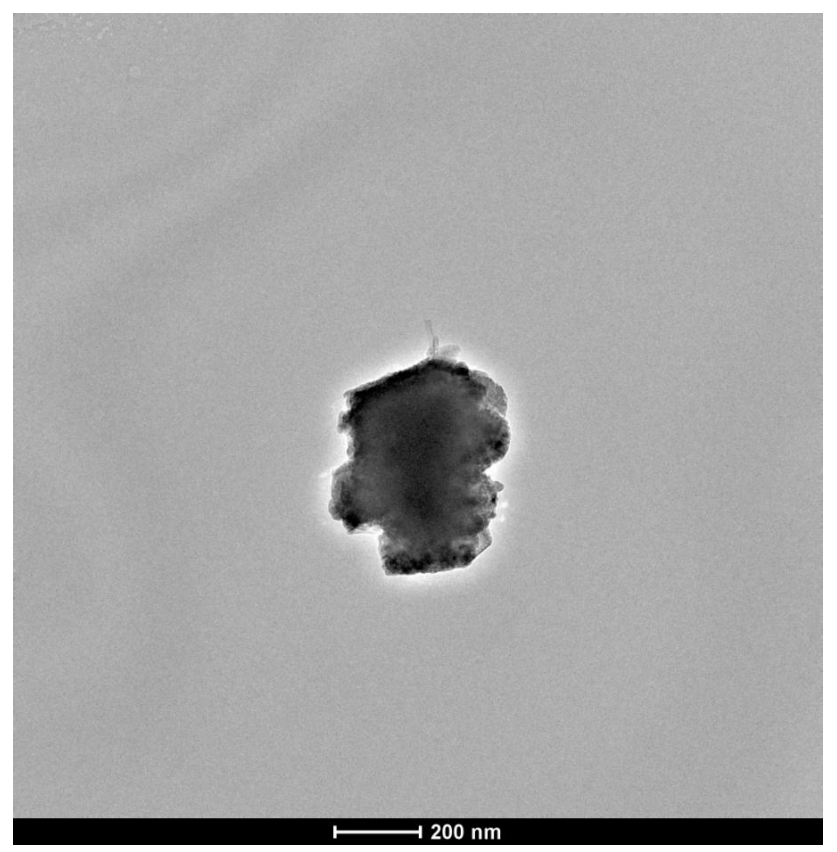

Figure 15. TEM image of an O-, S-, Ti-, Sr-, and Ba-containing particle from a deep-seated oxidized zone in the Dongshengmiao deposit.

sulfur-containing particles in an ascending gas flow; for example, the mean sulfur concentrations of Devonian limestone, mudstone, siltstone, and sandstone in the northern

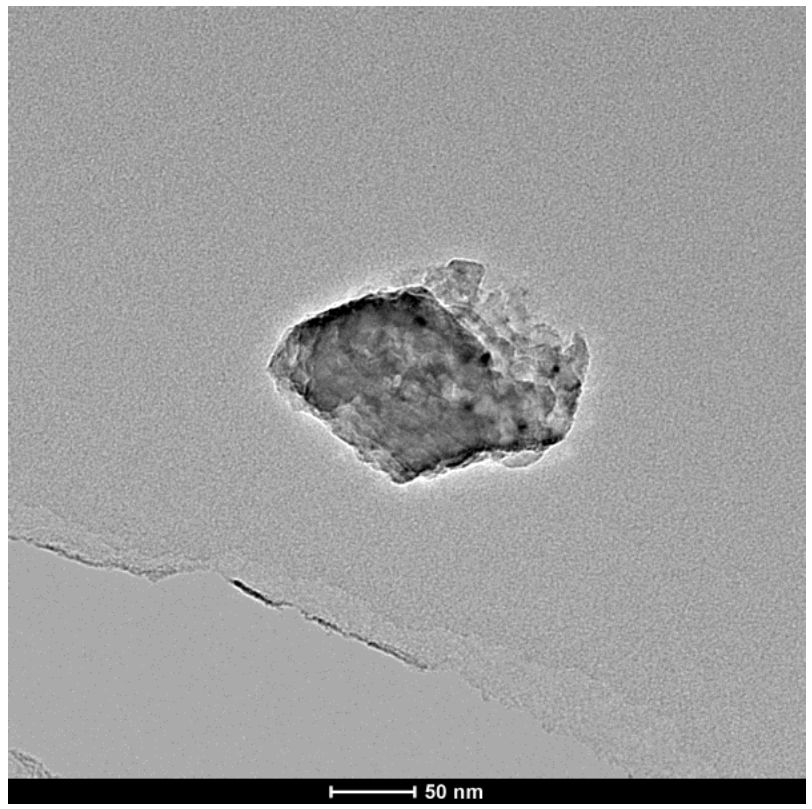

Figure 16. TEM image of an O-, S-, Fe-, Co-, and Ca-containing particle from a deep-seated fault gouge in the Dongshengmiao deposit.

Guangdong province, China are $610 \times 10^{-6}$ (68 samples), $80 \times 10^{-6}$ ( 25 samples), $160 \times 10^{-6}$ (33 samples), and $110 \times$ $10^{-6}$ sulfur (4 samples), respectively.

The estimated rate of degassing for the Dongshengmiao deposit was calculated to be $2.325 \mathrm{~m}^{3} \mathrm{~s}^{-1}$. The mean sulfur content of the particles carried by the ascending geogas flow for the Dongshengmiao deposit was calculated according to $45 \mathrm{mg} \mathrm{m}^{-3}$ (Supplement). The estimated annual sulfur emission from particles in the deposit was 3.254 tons. Qi et al. (2007) reported a flue gas amount of $527300 \mathrm{~m}^{3} \mathrm{~h}^{-1}$ from the Huhehaote power plant in China and an exit particle concentration of $43.3 \mathrm{mg} \mathrm{m}^{-3}$ carried by the flue gas. The $\mathrm{SO}_{3}$ distribution range in fly ash in 14 power plants (e.g. Tangshan power plant, Gaojing power plant, and Zhengzhou power plant) was reported to range between 0 and $1.05 \%$. The mean $\mathrm{SO}_{3}$ and sulfur contents in fly ash were 0.27 and $0.108 \%$, respectively. On the basis of these mean values, $21.305 \mathrm{t}$ of annual particulate sulfur emission occurred from the flue gas in the Huhehaote power plant. The annual sulfur emission from the particles carried by ascending geogas flow in the Dongshengmiao deposit was less than carried by the flue gas in the Huhehaote power plant. However, the amount of concealed deposits is much more than that in coal-burning power plants. Moreover, size of the particles carried by the ascending geogas flow from concealed deposits is usually $<500 \mathrm{~nm}$. The mean diameter of the particles carried by the flue gas in nine samples obtained from four coal-fired power plants in China were 19.71, 3.18, 5.43, 5.67, 130.94, 77.29, $12.99,11.59$, and $236.63 \mu \mathrm{m}$ (Zhang et al., 2005). The sizes 
of particles carried by the ascending geogas flow from concealed deposits were lesser than those of the particles carried by the flue gas from coal-fired power plants. Within a certain volume, the particles were smaller and the number of particles was more. These small particles are more capable of migration and have a significant health and environmental impact. Therefore, attention must be paid to the particles carried by the ascending geogas flow from concealed deposits.

Such sulfur-containing particles enter the atmosphere. Several studies have discussed the direct effects of sulfate particles on the climate (Liu et al., 2009). Some researchers have suggested that sulfur-containing particles can reduce atmospheric temperature or result in climate warming. Streets et al. (2000) suggested that because sulfate aerosols play a vital role in cooling the atmosphere, a reduction in sulfur dioxide emissions in the future would result in increased global warming. Furthermore, aerosol sulfate has been identified as an important contributor to sunlight scattering (Lelieveld and Heintzenberg, 1992; Kim et al., 2001). At the top of the atmosphere above East Asia, $\mathrm{SO}_{4}^{2-}$ radiative forcing is -2 to $-10 \mathrm{~W} \mathrm{~m}^{-2}$ over land and -5 to $-15 \mathrm{~W} \mathrm{~m}^{-2}$ over ocean (Gao et al., 2014). Niemeier et al. (2011) revealed that an increase in the $\mathrm{SO}_{2}$ emission rate does not lead to a similar increase in radiative forcing because, as the size of the aerosols increases, their lifetime decreases. It is thus possible that the sulfur-containing particles transported by an ascending geogas flow have an effect on the climate and should, therefore, be evaluated.

Sulfate particles can be transported into the lungs leading to respiratory illnesses (World Bank Group, 1999; Soleimani et al., 2007). In particular, the sulfur-containing particles contain high levels of toxic $\mathrm{Pb}, \mathrm{Hg}, \mathrm{Cu}$, and As. In nature, sulfur usually combines with $\mathrm{Pb}, \mathrm{Hg}, \mathrm{Cu}, \mathrm{As}, \mathrm{Ni}, \mathrm{Cd}$, and $\mathrm{Sb}$, which are toxic to organisms, to form sulfide deposits. The sulfur-containing particles originating from sulfide deposits commonly contain toxic elements. This phenomenon has been confirmed by EDX analysis of particles. The particle sizes carried by the ascending gas flow are usually less than $500 \mathrm{~nm}$. The size is only one-fifth of the upper size limit of $\mathrm{PM}_{2.5}$. Geogas particles undergo long-distance migration. They can remain in the atmosphere for long periods and can get into bronchioles and alveoli, affecting the ventilative function of lung. They can also enter the blood. The possible relationship between the occurrence of sulfurcontaining particles transported by an ascending geogas flow and endemic diseases in the vicinity of sulfur-containing deposits should be investigated.

It is probable that sulfur-containing particles transported by the ascending geogas flows in the soil affect the soil system; for example, sulfur-containing particles can affect both soil biota and enzymatic activities, resulting in changes in the soil structure, nutrient cycling, and organic matter decomposition and retention. Sulfur-containing particles may directly catalyze organic matter decomposition. Furthermore, the po- tential use of such particles as fertilizers for rice plants needs to be investigated.

\section{The Supplement related to this article is available online at doi:10.5194/acp-15-6959-2015-supplement.}

Acknowledgements. Financial support from the National Natural Science Foundation of China (grant nos. 41030425, 41072263, 40773037, and 40673044) and the National High-Tech Research and Development Program of China (863 program; grant no. 2008AA06Z101) is gratefully acknowledged.

Edited by: A. Laaksonen

\section{References}

Andres, R. J., Rose, W. I., Stoiber, R. E., Williams, S. N., Matías, O., and Morales, R.: A summary of sulfur dioxide emission rate measurements from Guatemalan volcanoes, B. Volcanol., 55, 379388, 1993.

Bao, H. M., Yu, S., and Tong, D. Q.: Massive volcanic $\mathrm{SO}_{2}$ oxidation and sulphate aerosol deposition in Cenozoic North America, Nature, 465, 909-912, 2010.

Berresheim, H.: Biogenic sulfur emissions from the Subantarctic and Antarctic Oceans, J. Geophys. Res., 92, 13245-13262, 1987.

Bhugwant, C., Siéja, B., Bessafi, M., Staudacher, T., and Ecormier, J.: Atmospheric sulfur dioxide measurements during the 2005 and 2007 eruptions of the Piton de La Fournaise volcano: Implications for human health and environmental changes, J. Volcanol. Geoth. Res., 184, 208-224, 2009.

Cao, J. J.: Migration mechanisms of gold nanoparticles explored in geogas of the Hetai ore district, southern China, Geochem. J., 45, e9-e13, 2011.

Cao, J. J., Hu, R. Z., Liang, Z. R., and Peng, Z. L.: TEM observation of geogas-carried particles from the Changkeng concealed gold deposit, Guangdong Province, South China, J. Geochem. Explor., 101, 247-253, 2009.

Cao, J. J., Hu, X. Y., Jiang, Z. T., Li, H. W., and Zou, X. Z.: Simulation of adsorption of gold nanoparticles carried by gas ascending from the Earth's interior in alluvial cover of the middle-lower reaches of the Yangtze River, Geofluids, 10, 438-446, 2010a.

Cao, J. J., Liu, C., Xiong, Z. H., and Qin, T. R.: Particles carried by ascending gas flow at the Tongchanghe copper mine, Guizhou Province, China, Science China Earth Sciences, 53, 1647-1654, 2010b.

Cao, J. J., Liu, C., Zhang, P., Li, Y. P., and Xiong, Z. H.: The characteristic of geogas particles from Daheishan basalt copper deposit in the Huize county of Yunnan, Mital Mine, 113-115, 2011 (in Chinese with English abstract).

Chenet, A. L., Fluteau, F., and Courtillot, V.: Modelling massive sulfate aerosol pollution, following the large 1783 Laki basaltic eruption, Earth Planet. Sci. Lett., 236, 721-731, 2005.

Etiope, G. and Martinelli, G.: Migration of carrier and trace gases in the geosphere: an overview, Phys. Earth Planet. In., 129, 185204, 2002. 
Gao, Y., Zhao, C., Liu, X. H., Zhang, M. G., and Leung, L. R.: WRF-Chem simulations of aerosols and anthropogenic aerosol radiative forcing in East Asia. Atmos. Environ., 92, 250-266, 2014.

Gieré, R. and Querol, X.: Atmospheric particles: solid particulate matter in the atmosphere, Elements, 6, 215-222, 2010.

Graf, H.-F., Langmann, B., and Feichter, J.: The contribution of Earth degassing to the atmospheric sulfur budget, Chem. Geol., 147, 131-145, 1998

Holub, R. F., Reimer, G. M., Hopke, P. K., Hovorka, J., Krcmar, B., and Smrz, P. K.: "Geoaerosols": their origin, transport and paradoxical behavior: a challenge to aerosol science, J. Aerosol Sci., 30, S111-S112, 1999.

Holub, R. F., Hovorka, J., Reimer, G. M., Honeyman, B. D., Hopke, P. K., and Smrz, P. K.: Further investigations of the "geoaerosol" phenomenon, J. Aerosol Sci., 32, 61-70, 2001.

Hu, G., Cao, J. J., Hopke, P. K., and Holub, R. F.: Study of carbonbearing particles in ascending geogas flows in the Dongshengmiao polymetallic pyrite deposit, Inner Mongolia, China, Resour. Geol., 65, 13-26, 2015.

Kim, B. G., Park, S. U., and Han, J. S.: Transport of $\mathrm{SO}_{2}$ and aerosol over the Yellow sea, Atmos. Environ., 35, 727-737, 2001.

Kristmannsdottir, H., Sigurgeirsson, M., Armannsson, H., Hjartarson, H., and Olafsson, M.: Sulfur gas emissions from geothermal power plants in Iceland, Geothermics, 29, 525-538, 2000.

Lelieveld, J. and Heintzenberg, J.: Sulfate cooling effect on climate through in-cloud oxidation of anthropogenic $\mathrm{SO}_{2}$, Science, 258, 117-120, 1992.

Liu, C., Cao, J. J., and Ke, H. L.: Geogas characteristic of Yongshengde copper ores in the Northeastern Yunnan, China, Geol. Chem. Minerals, 33, 201-207, 2011 (in Chinese with English abstract).

Liu, Y., Sun, J. R., and Yang, B.: The effects of black carbon and sulfate aerosols in China regions on East Asia monsoons, Tellus B, 61, 642-656, 2009.

Niemeier, U., Schmidt, H., and Timmreck, C.: The dependency of geoengineered sulfate aerosol on the emission strategy, Atmos. Sci. Lett. Special Issue: Geoengineering, 12, 189-194, 2011.

Pósfai, M., Anderson, J. R., and Buseck, P. R.: Soot and sulfate aerosol particles in the remote marine atmosphere, in: Geological Society of America, 1997 annual meeting, Abstracts with Programs - Geological Society of America, 29, 357, 1997.

Qi, L. Q., Yuan, Y. T., and Liu, J.: Current situations of emission and collection on fly ash of power plants in China: International Conference on Power Engineering-2007, Hangzhou, China, 2327 October 2007, 766-772, 2007.

Rose, W. I., Chuan, R. L., Giggenbach, W. F., Kyle, P. R., and Symonds, R. B.: Rates of sulfur dioxide and particle emissions from White Island volcano, New Zealand, and an estimate of the total flux of major gaseous species, B. Volcanol., 48, 181-188, 1986.

Seino, N., Sasaki, H., Sato, J., and Chiba, M.: High-resolution simulation of volcanic sulfur dioxide dispersion over the Miyake Island, Atmos. Environ., 38, 7073-7081, 2004.
Sinninghe Damsté, J. S., Irene, W., Rijpstra, C., de Leeuw, J. W., and Schenck, P. A.: Origin of organic sulfur compounds and sulfurcontaining high molecular weight substances in sediments and immature crude oils, Org. Geochem., 13, 593-606, 1988.

Soleimani, M., Bassi, A., and Margaritis, A.: Biodesulfurization of refractory organic sulfur compounds in fossil fuels, Biotechnol. Adv., 25, 570-596, 2007.

Streets, D. G., Tsai, N. Y., Akimoto, H., and Oka, K.: Sulfur dioxide emissions in Asia in the period 1985-1997, Atmos. Environ., 34, 4413-4424, 2000.

Sweeney, D., Kyle, P. R., and Oppenheimer, C.: Sulfur dioxide emissions and degassing behavior of Erebus volcano, Antarctica, J. Volcanol. Geoth. Res., 177, 725-733, 2008.

Tong, C. H. and Li, J. C.: A new method searching for concealed mineral resources: geogas prospecting based on nuclear analysis and accumulation sampling, J. China Univ. Geosci., 10, 329-332, 1999.

Trabue, S., Scoggin, K., Mitloehner, F., Li, H., Burns, R., and Xin, H. W.: Field sampling method for quantifying volatile sulfur compounds from animal feeding operations, Atmos. Environ., 42, 3332-3341, 2008.

Wei, X. J., Cao, J. J., Holub, R. F., Hopke, P. K., and Zhao, S. J.: TEM study of geogas-transported nanoparticles from the Fankou Lead-Zinc Deposit, Guangdong Province, South China, J. Geochem. Explor., 128, 124-135, 2013.

Williams, K. D., Jones, A., Roberts, D. L., Senior, C. A., and Woodage, M. J.: The response of the climate system to the indirect effects of anthropogenic sulfate aerosol, Clim. Dynam., 17, 845-856, 2001.

Wong, M. H.: An ecological survey of the effect of sulfur dioxide emitted from an Acid Work Factory, B. Environ. Contam. Tox., 19, 715-723, 1978.

World Bank Group: Pollution prevention and abatement handbook: towards cleaner production, World Bank Group Publishers, Washington D.C., 1999.

Wu, T., Wang, X. M., Li, D. J., and Yi, Z. G.: Emission of volatile organic sulfur compounds (VOSCs) during aerobic decomposition of food wastes, Atmos. Environ., 44, 5065-5071, 2010.

Yang, F. G. and Tong, C. H.: Geogas anomaly and mechanism in Xuanhan gas field, Earth Science-J. China University of Geosciences, 25, 103-106, 2000 (in Chinese with English abstract).

Yang, Z., Kanda, K., Tsuruta, H., and Minami, K.: Measurement of biogenic sulfur gases emission from some Chinese and Japanese soils, Atmos. Environ., 30, 2399-2405, 1996.

Yang, Z., Kong, U. L., Zhang, J., Wang, L., and Xia, S.: Emission of biogenic sulfur gases from Chinese rice paddies, Sci. Total Environ., 224, 1-8, 1998.

Zhang, C. F., Yao, Q., and Sun, J. M.: Characteristics of particulate matter from emissions of four typical coal-fired power plants in China, Fuel Process Technol., 86, 757-768, 2005.

Zreda-Gostynska, G., Kyle, P., and Finnegan, D.: Chlorine, fluorine, and sulfur emissions from Mount Erebus, Antarctica and estimated contributions to the Antarctic atmosphere, Geophys. Res. Lett., 20, 1959-1962, 1993. 